\title{
PREFACE
}

Philip Brett died in October 2002 on the eve of his sixty-fifth birthday. He is mourned by his many friends and admirers for his learning, lightly worn, his sensitivity, elegance, passionate activism, and exquisite musicality. His two signal contributions to musical studies extend over so wide a range that they might seem to come from different worlds. In the r97os he was the first to break the taboo on the open discussion of composers' sexuality, and as he followed up on his powerful, subtle investigation of Benjamin Britten's Peter Grimes with further work on Britten operas, he became musicology's pioneer in gender studies and queer theoryknown for polemics and forthright activism, not only scholarly writings.

A companion volume to this one, edited by George Haggerty, Music and Sexuality in Britten: Selected Essays, has been published by the University of California Press. After two years at King's College Cambridge, Philip spent his academic career at the University of California, first at the Berkeley campus and then at Riverside and Los Angeles.

Before that he had established himself in Renaissance studies, where he will be remembered principally as an editor, in particular as general editor of the works of the great Elizabethan composer William Byrd. He launched a new complete edition-The Byrd Edition-in the wake of an inadequate earlier one, which was floundering in revisions. Philip's in- 
tervention could be described as a rescue, for without him it is hard to believe the edition would have happened at all. He edited eight of the volumes himself-the Masses and the Gradualia, the consort songs and a volume of miscellaneous madrigals and songs—and brought the long undertaking (virtually) to completion. While his turn to Britten and gender studies made him a main precursor of the so-called new musicology of the ig8os, a musicology oriented toward hermeneutics, his work in the Renaissance preserved musicology's traditional emphasis on sources, historical analysis, and the establishment of texts. These zones of engagement were not altogether disparate, as he was well aware, and as we will see in a moment.

Musicology in Britain after World War II took its lead from Thurston Dart, and Philip Brett was Dart's star pupil. His affinity for the Elizabethan Golden Age, his nose for sources, his love of editing, his commitment to musical performance-all these and more resonated with Dart, who drew him into collaboration with several of his own editing jobs. (He took over two of Byrd's songbooks in Dart's revision of the earlier Byrd edition, by E. H. Fellowes: the Psalmes, Sonets \& Songs of 1588 and Songs of Sundrie Natures of 1589). While still a student, he made two discoveries of moment in the field of Elizabethan music, establishing the provenance of a very large group of sources for vocal polyphony of the era, known as the Paston manuscripts, and identifying a group of consort songs preserved anonymously by Paston as late works by Byrd. (They remain, as of today, the last major addition to the canon.) Indeed, he named the genre "consort song"-earlier scholars had described it but never focused on it - and published the entire corpus in volume 15 of The Byrd Edition and volume 22 of Musica Britannica. When he addressed the Royal Musical Society on the subject of "The Consort Song, I570-1615" in I96r, at a time when all papers were invited, he must have been the youngest speaker ever tapped.

Philip Brett became an exemplary editor, one who not only obsessed about minutiae in his text and, indeed, developed new ways of establishing it, but also assumed as full responsibility as he could for the music he 


\section{Preface / ix}

edited. He sang it, researched it, and wrote about both the music and the research in commentaries of unusual extent and richness. It was in these commentaries and in his essays that he displayed his art as a historian and critic. This was especially true of his work on Gradualia, the large, twovolume collection of more than a hundred "sacred songs" (or motets) and motet segments for the Roman Catholic liturgy and private devotions, which Byrd published near the end of his career, in 1605 and 1607 - his magnum opus. The edition, with its extraordinary book-length commentary, issued serially from I989 to I997, became Philip's magnum opus too.

Yet this was also the juncture for him where past and present, old musicology and new musicology, came together. The collection, he recognized, "had to be approached not simply as the fervent work of a remarkable composer but also as a peculiar manifestation of a set of unusual religious and cultural circumstances." In a postscript to his Cambridge Opera Handbook to Peter Grimes, he spoke about the impetus behind his work on Britten: "My ultimate concern is the social experience of oppression and its effects in the writing of Peter Grimes, not Britten's sexual preference. With appropriate changes to fit the conditions, I might write similarly about the social accommodation of another of England's greatest composers, William Byrd, who experienced another kind of oppression that affected his music."

Gradualia was written and published for a persecuted minority, the recusant Roman Catholic community in England under Elizabeth I and James I. Philip made the connection with the cultural and political circumstances of present-day minorities on whose behalf he had taken up arms, as well as pen. Once he began examining the publication deeplyexamining the printing process itself, which he was able to track in unusual detail; the confusing (sometimes confused) order of the contents in each of the two volumes; and especially the texts, with their arcane, explosive subtexts- he began to hear the music anew, and a radical interpretation emerged of Byrd's whole undertaking. A particular insight was that in setting the texts, Byrd considered not only their liturgical functions and biblical sources, but also the interpretation of those sources in 
a central polemical document of the time, the Douay-Rheims Bible, translated for the English Catholics and brought out serially during the composer's lifetime with profuse annotations. The Douay-Rheims annotations, Philip proposed, provide a key to the musical setting of many of Gradualia's most striking numbers. In short, he saw Gradualia as a political act of defiance, one that in its own time placed new demands on Byrd's creative energies, and that now presents its own challenge to contemporary hermeneutics.

The outcome of all this was a series of five outsized prefaces, initiating the five volumes needed for Gradualia in the format of The Byrd Edition. As these volumes appeared one by one over a period of eight years, the study's true power was not immediately evident. Nor was the place where this research appeared conducive to the circulation it deserved. Philip intended to collate the prefaces and make them into a monograph (he even began drawing up an introduction for this monograph). To realize his intention is to pay him an apt tribute and to perform the important function, as we see it, of focusing some very bright light on the life and works of William Byrd.

Thus the final chapter (or, better, segment) of the present book brings together Philip's writings on Gradualia for the first time as an entity. And no document brings together his work as social historian, philologist, and critic more perfectly. The editors-Joseph Kerman, briefly his teacher and his longtime colleague at Berkeley, and Davitt Moroney, his student and collaborator-were both closely involved with the Gradualia project, and indeed we mapped out "Prefaces to Gradualia" even before a larger collection of Philip Brett's writings on Tudor and Jacobean music came under consideration.

Most of the other essays have been published before, sometimes in sources that are now hard to find; that they refer to so many of Byrd's contemporaries - the composers John Taverner, Thomas Tallis, Thomas Weelkes, and Orlando Gibbons, as well as the collector Edward Paston and the emblematist Geoffrey Whitney-provides, once again, a measure of the breadth of this scholar's purview. Some of the essays are 


\section{Preface / xi}

addressed to his fellow musicologists, others to his fellow musicians. They range from the report of his findings on the Paston manuscriptshis first musicological coup, already accomplished in I960-to an unpublished roundtable paper that he delivered a few months before his death (from two versions of this paper, filed on Philip's computer as “ 'Blame not the Printer': William Byrd's Publishing Drive, I588-91" and "Byrd's Soul Authority," we have abstracted a short chapter with the title "William Byrd: New Reflections"). Philip was a stylist, and apart from this case his own words have been left strictly alone, as free as possible from the depredations of editors and copyeditors.

A word on the opening chapter, which in its original form annotated a concert celebrating the 45oth anniversary of Byrd's birth, given at Riverside and Claremont, California, in r993. (Until recently Byrd was thought to have been born in I543; the date has now been moved back to I540. $)^{2}$ With only the slightest of editing, we think it makes a beautiful concise introduction to the composer, and while certainly the author would have revised it for inclusion in a book, also certainly he would have wanted such a book to acknowledge, up front, his commitment to musical performance. His work as a conductor, keyboard player, and violist meant at least as much to Philip as musicology. Those who lived around him will not forget his performances of Gradualia and a wealth of other music, from Ockeghem and Josquin Desprez via the Monteverdi Vespers, The Fairy Queen, Susanna, and the B-Minor Mass to Benjamin Britten and beyond.

Many of Philip's friends have helped with this book: most substantially George Haggerty and O. W. Neighbour, and Larry W. Allen, Kerry McCarthy, William Mahrt, Craig Monson, Louis A. Montrose, and William A. Peterson. In the area of production we are very grateful to Mary Francis and Lynne Withey of the University of California Press for their strong support and guidance and to Rebekah Ahrent, Michael Markham, and Camille Peters of the Berkeley Music Department for editorial assistance. Walter Frisch intervened most kindly at the last minute to help with permissions. The editors gratefully acknowledge the generous con- 
tribution to this book provided by the Edmund O'Neill Fund at the University of California.

We thank the following publishers and organizations for permission to reprint material that they first published or for which they now hold the rights: the Southern California Early Music Society (chapter I), Oxford University Press (chapters 2, 3, 6, and 8), the Cambridge Bibliographical Society (chapter 4), The Lute Society (chapter 5), and Stainer $\&$ Bell Ltd. (chapters 7 and ro). Special thanks are due to Carol Wakefield of Stainer \& Bell for granting permission to assemble and reprint the prefaces to Gradualia from The Byrd Edition. In his own acknowledgment pages Philip spoke warmly of his long and fruitful association with Allen Percival, former publisher and editor at Stainer \& Bell. We wish also to acknowledge the firm's deep and even longer commitment to Elizabethan and Jacobean music.

Berkeley, October 2005

Foseph Kerman

Davitt Moroney

\section{NOTES}

I. Philip Brett, ed., Benjamin Britten: Peter Grimes Cambridge Opera Handbook Series (Cambridge, I983), I92.

2. The earlier date rests on new archival studies and seems solid to us, as it seemed to Philip, even though it has not been accepted universally. See John Harley, William Byrd: Gentleman of the Chapel Royal (Brookfield, VT, 1997) and the Oxford Dictionary of National Biography. 